\title{
MEMBANGUN KELUARGA HARMONIS MELALUI CINTA DAN SPIRITUALITAS PADA PASANGAN SUAMI-ISTRI DI PROVINSI JAWA TIMUR
}

\author{
Rahmat $\mathrm{Aziz}^{\left.1^{*}\right)}$, Retno Mangestuti ${ }^{1}$ \\ ${ }^{1}$ Fakultas Psikologi, Universitas Islam Negeri Maulana Malik Ibrahim Malang, Malang 65144, Indonesia
}

")E-mail: azira@uin-malang.ac.id

\begin{abstract}
Abstrak
Keharmonisan keluarga merupakan tujuan dari setiap pernikahan yang dapat dicapai dengan adanya usaha dari pasangan suami-istri untuk saling mencintai dan mengembangkan perilaku spiritual dalam kehidupan berkeluarga. Penelitian ini bertujuan untuk menganalisis peran spiritualitas sebagai variabel moderator yang mampu memperkuat hubungan antara cinta dan keharmonisan keluarga. Data diperoleh dari 410 pasangan suami-istri (205 suami dan 205 istri) di tujuh kota (Malang, Surabaya, Pasuruan, Jember, Blitar, Batu, dan Jombang) yang ada di Provinsi Jawa Timur. Data diperoleh melalui alat ukur The Family Harmony Scale, The Triangular of Love Scale, dan Daily Spiritual Experience Scale. Data dianalisis menggunakan teknik deskriptif dan regresi. Hasil analisis menunjukkan bahwa cinta berpengaruh signifikan terhadap keharmonisan keluarga $(\beta=0,625 p<0,01)$, dan spiritualitas mampu menjadi variabel yang memperkuat hubungan antara cinta dengan keharmonisan keluarga $(\beta=0,688 p<0,01)$. Hasil penelitian ini berimplikasi bahwa memupuk perasaan cinta pada pasangan suami-istri dapat mewujudkan keharmonisan dan untuk memperkuat hubungan tersebut maka pasangan perlu mengembangkan spiritualitas dalam kehidupan sehari-hari.
\end{abstract}

Kata kunci: cinta, kebersamaan, keharmonisan keluarga, keintiman, spiritualitas

\section{Building a Harmonious Family Through Love and Spirituality on Married Couples in East Java Province}

\begin{abstract}
Family harmony is the goal of every marriage that can be achieved by the efforts of husband and wife to love each other and develop spiritual behaviour in family life. This study aimed to analyze the role of spirituality as a moderating variable that can strengthen the relationship between love and family harmony. Data were obtained from 410 married couples (205 husbands and 205 wives) in seven cities (Malang, Surabaya, Pasuruan, Jember, Blitar, Batu, and Jombang) in East Java Province. The data were obtained by measuring the Family Harmony Scale, The Triangular of Love Scale, and the Daily Spiritual Experience Scale. The data were analyzed using descriptive and regression techniques. The results of the analysis showed that love had a significant effect on family harmony $(\beta=0.625 p<0.01)$, and spirituality could be a variable that strengthened the relationship between love and family harmony $(\beta=0.688 p<0.01)$. This study implies that cultivating feelings of love in married couples can create harmony and strengthen the relationship, the couple needs to develop spirituality in everyday life.
\end{abstract}

Keywords: family harmony, intimacy, love, spirituality, togetherness

\section{PENDAHULUAN}

Setiap pasangan yang menikah mengharapkan adanya keharmonisan yang mana semua anggota keluarga merasa nyaman dan damai berada di dalamnya. Namun demikian, angka perceraian di Indonesia menunjukkan adanya peningkatan. Data Badan Pusat Statistik (2018, 2019) menunjukkan bahwa pada tahun 2016 perceraian di Jawa Timur berjumlah 86,491 kasus, pada tahun 2018 meningkat menjadi 88,955 kasus, dan tahun 2019 melonjak menjadi 95,007 kasus. Penelitian yang dilakukan Maimun, Toha, dan Arifin (2019) menemukan bahwa tingginya tingkat perceraian di Jawa Timur sebagai akibat dari seringnya terjadi perselisihan di antara pasangan, kesulitan ekonomi, dan terjadinya kekerasan dalam rumah tangga.

Tingginya angka perceraian tersebut menunjukkan bahwa keharmonisan keluarga sebagai tujuan yang diharapkan dapat terwujud ternyata di lapangan masih menyisakan berbagai permasalahan yang memerlukan perhatian. Kondisi ini mengisyaratkan tentang pentingnya mengkaji keharmonisan keluarga sebagai satu kajian yang mendesak untuk di lakukan (Hamidah, 2019) oleh berbagai pihak, dengan berbagai pendekatan yang berbeda. 
Banyak faktor yang diduga menjadi penyebab terjadinya perceraian. Wijayanti (2021) menemukan bahwa usia, pendidikan, lama pernikahan, dan ekonomi sebagai faktor yang berpengaruh terhadap perceraian. Selain itu, ditemukan juga bahwa perselisihan antara suami-istri merupakan faktor yang paling tinggi sebagai penyebab terjadinya perceraian. Hasil ini didukung dengan temuan Bainah (2013) yang menyatakan bahwa tingkat pendidikan yang rendah, jenis pekerjaan, tingkat ekonomi yang rendah, adanya masalah moralitas, dan tingginya tingkat kekerasan dalam keluarga adalah beberapa faktor yang menjadi penyebab terjadinya perceraian dalam keluarga.

Lebih lanjut, penelitian Nasir (2012) menemukan adanya tambahan selain dari faktor tersebut, yaitu kawin paksa yang dilakukan oleh orang tua pada anaknya. Temuan di atas menarik untuk dicermati lebih lanjut, mengingat dalam kasus kawin paksa, proses pernikahan tidak didasari perasaan saling cinta antara keduanya. Padahal cinta merupakan faktor penting yang memengaruhi terhadap terwujudnya keharmonisan dalam keluarga (Gana, Saada, \& Untas, 2013).

Beberapa penelitian yang mengkaji tentang faktor ekonomi, sosial budaya, dan psikologis yang memengaruhi keharmonisan keluarga telah banyak dilakukan. Penelitian yang mengkaji faktor ekonomi telah dilakukan oleh Chrisman, Chua, dan Pearson (2012) yang menemukan bahwa ekonomi mempunyai peran yang penting dalam kehidupan berkeluarga. Selain itu, penelitian Larasati (2012) menemukan bahwa kepuasan perkawinan dipengaruhi oleh keterlibatan suami dalam memenuhi tuntutan ekonomi keluarga. Penelitian terkait faktor sosial budaya yang memengaruhi keharmonisan juga telah dilakukan oleh Fitriyani, Suryadi, dan Syam (2015) yang meneliti tentang peran keluarga dalam mengembangkan nilai luhur budaya sunda, Lorenzo et al. (2012) terkait urgensi nilai-nilai budaya dalam kehidupan berkeluarga, serta Roksa dan Kinsley (2019) terkait peran fungsi keluarga sebagai fasilititator dalam mengembangkan kesuksesan akademik.

Lebih lanjut, penelitian terkait faktor psikologis telah dilakukan oleh Darokah dan Safaria (2012) yang menemukan adanya hubungan antara keberagamaan kepribadian dengan keharmonisan keluarga dan penelitian Herawati et al. (2020) yang menunjukkan bahwa keluarga mampu berfungsi untuk mengembangkan dan melestarikan nilai-nilai agama. Ada banyak faktor yang diduga berpengaruh terhadap tercapainya keharmonisan keluarga, diantaranya adalah faktor cinta dan spiritual. Sternberg (1997) menyatakan bahwa cinta merupakan variabel yang memiliki tiga komponen yang saling berkaitan satu dengan lainnya. Ketiga komponen tersebut adalah keintiman, kegairahan, serta komitmen.

Keintiman mengacu pada kedekatan dan rasa nyaman antara suami-istri. Kegairahan mengacu pada dorongan yang bersifat romantis, daya tarik fisik, dan hubungan seksual antara suami-istri. Komitmen yaitu komponen yang mengacu pada suatu keputusan untuk mempertahankan hubungan dalam cinta. Pengaruh ketiga komponen tersebut akan semakin kuat ketika pasangan suami-istri memiliki tingkat spiritualitas yang tinggi (Hardy et al., 2014).

Suatu keluarga disebut sebagai keluarga yang harmonis apabila anggota keluarga tersebut merasa damai dan bahagia dalam menjalani kehidupannya. Kondisi ini dapat dicirikan dengan berkurangnya rasa tegang, rasa cemas, rasa kecewa, serta munculnya perasaan puas terhadap seluruh kondisi dan keberadaan anggota keluarga (Lam et al., 2012). Keluarga dalam perpektif teori sistem diartikan sebagai sebuah sistem yang mana setiap anggota memiliki peran, dan untuk memainkan peran tersebut perlu tetap menghormati aturan yang ada. Sebagai sebuah sistem, setiap anggota diharapkan mampu merespon antara satu sama lain sesuai dengan peran dirinya masing-masing (Johnson \& Ray, 2016). Pada sebuah sistem keluarga, diperlukan komunikasi yang efektif dan efisien sehingga terhindar dari kesalahpahaman dalam berinteraksi.

Beberapa penelitian tentang keharmonisan keluarga telah dilakukan baik yang menempatkannya sebagai variabel bebas (Banker \& Gaertner, 1998; Chrisman et al., 2012) maupun sebagai variabel terikat (Chuang, 2005; Perry, Harris, \& Minnes, 2005; Slaughter, 2009). Penelitian tentang keharmonisan keluarga yang menghubungkan dengan variabel cinta telah dilakukan dengan berbagai pendekatan dan disiplin ilmu (Gana et al., 2013; Haack \& Falcke, 2014; Neto, 2012). Demikian juga, penelitian yang menguji hubungan antara spiritualitas, termasuk kajian mengenai religiusitas dengan keharmonisan keluarga, telah dilakukan dengan berbagai bentuk dan pendekatan (David \& Stafford, 
2015; Hardy et al., 2014; Siroj, Sunarti, \& Krisnatuti, 2019).

Beberapa penelitian tersebut lebih banyak menempatkan keharmonisan keluarga sebagai variabel bebas dan terikat. Penelitian yang menguji hubungan antara cinta dan keharmonisan keluarga lebih memfokuskan pada pengujian pengaruh secara langsung. Penelitian ini memfokuskan pada pengaruh cinta terhadap keharmonisan keluarga dengan menjadikan spiritualitas sebagai variabel moderator yang mampu memperkuat hubungan antara kedua variabel tersebut.

Penelitian ini bertujuan untuk: 1) mengidentifikasi secara rinci gambaran empiris tentang keharmonisan keluarga, cinta, dan spiritualitas pada subjek penelitian. Identifikasi yang dimaksud adalah pengklasifikasian tingkat keharmonisan keluarga, cinta, dan spiritualitas menjadi tiga kategori yaitu tinggi, sedang, dan rendah. Klasifikasi tersebut dilakukan juga pada setiap indikator dari variabel tersebut; 2) menganalisis pengaruh cinta yang dicirikan dengan keintiman, kegairahan, dan komitmen terhadap keharmonisan keluarga. Analisis dilakukan secara simultan bertujuan untuk menguji pengaruh cinta terhadap keharmonisan keluarga dan secara parsial bertujuan untuk menguji pengaruh keintiman, kegairahan, dan komitmen terhadap keharmonisan keluarga; dan 3) menganalisis peran spiritualitas sebagai variabel moderator yang mampu memperkuat pengaruh variabel cinta terhadap keharmonisan keluarga pada pasangan suami-istri di Provinsi Jawa Timur.

\section{METODE}

Penelitian menggunakan desain cross-sectional study dengan pendekatan kuantitatif jenis eksplanatif. Subjek penelitian adalah pasangan suami-istri di tujuh kota di Provinsi Jawa Timur. Ketujuh kota yang dijadikan tempat penelitian yaitu Malang, Surabaya, Pasuruan, Jember, Blitar, Batu, dan Jombang. Teknik pengambilan sampel dilakukan secara purposif dengan mempertimbangkan hal-hal sebagai berikut: 1) subjek merupakan suami-istri yang menikah secara sah; 2) subjek merupakan pasangan yang tinggal bersama dalam satu rumah; 3) usia perkawinan lebih dari 1 (satu) tahun; dan 4) bersedia menjadi subjek penelitian. Pengujian validitas ketiga alat ukur dilakukan pada 110 subjek pasangan suami-istri (55 orang suami dan 55 orang istri), adapun responden untuk menguji hipotesis berjumlah 410 subjek yang terdiri atas 205 orang suami dan 205 orang istri.
Prosedur penelitian diawali dengan pengajuan proposal untuk mendapatkan dana hibah tahun 2019 dari Dirjen Pendidikan Tinggi Agama Islam (Diktis), Kementrian Agama Republik Indonesia (Kemenag RI) melalui Lembaga Penelitian dan Pengabdian pada Masyarakat (LP2M) Universitas Islam Negeri (UIN) Maulana Malik Ibrahim Malang. Setelah proposal dinyatakan diterima, proses selanjutnya adalah mengurus surat perijinan pada berbagai pihak untuk mengambil data penelitian. Pengambilan data dibantu oleh beberapa mahasiswa S1 Fakultas Psikologi dan mahasiswa Pascasarjana UIN Maulana Malik Ibrahim Malang.

Proses pengambilan data dilakukan selama lima bulan terhitung sejak bulan April sampai Agustus 2019. Setelah data terkumpul, kemudian diseleksi untuk diperiksa kelengkapan jawaban yang diberikan subjek dalam kuesioner. Selanjutnya, data ditabulasi dan disajikan dalam bentuk file exel yang siap untuk dianalisis dengan menggunakan analisis statistik parametrik.

Keharmonisan keluarga merupakan kondisi keluarga yang serasi dan mampu menciptakan kebahagiaan bagi semua anggota keluarga. Data ini diperoleh melalui alat ukur The Family Harmmony Scale (FHS) yang telah dibuat oleh Kavikondala et al. (2016). Alat ukur ini mampu mengungkap keharmonisan keluarga dari lima indikator yaitu: 1) kebiasaan untuk menggunakan komunikasi secara efektif; 2) kemampuan untuk menyelesaikan konflik yang terjadi dalam keluarga; 3) kesabaran dalam menjalin hubungan antara anggota keluarga; 4) kebanggaan dengan identitas yang dimiliki oleh keluarga; dan 5) kebiasaan menggunakan waktu dengan keluarga secara berkualitas. Alat ukur ini terdiri atas 24 butir pernyataan dan menggunakan skala Likert dengan lima alternatif jawaban, yaitu: 1) sangat tepat seperti keadaan saya; 2) seringkali seperti keadaan saya; 3) hampir seperti keadaan saya; 4) sedikit seperti keadaan saya; dan 5) tidak seperti keadaan saya. Hasil uji reliabilitas terhadap alat ukur keharmonisan keluarga menunjukkan bahwa seluruh butir yang diuji adalah valid dengaan nilai Cronbach's alpha sebesar $\alpha=0,961$. Contoh butir pernyataan dari alat ukur ini adalah "Anggota keluarga merasa peduli antara satu dengan yang lain".

Cinta adalah kondisi emosional yang berasal dari perasaan kasih sayang yang kuat dan ketertarikan dari seorang laki-laki terhadap perempuan, atau sebaliknya. Data ini diperoleh melalui alat ukur The Sternberg Triangular Love 
Scale yang dibuat oleh Sternberg (1997). Alat ukur ini mampu mengungkap cinta dari tiga indikator, yaitu: 1) keintiman (Intimacy) yaitu elemen emosi yang didalamnya terdapat kehangatan, kepercayaan, dan keinginan untuk membina hubungan; 2) kegairahan (passion) yaitu elemen motivasional yang didasari oleh dorongan dari dalam diri yang bersifat seksual; dan 3) komitmen (commitment) yaitu elemen kognitif berupa keputusan untuk melanjutkan dan tetap menjalankan suatu kehidupan bersama. Alat ukur ini terdiri atas 36 butir pernyataan dan menggunakan skala Likert dengan lima alternatif jawaban, yaitu: 1) sangat tepat seperti keadaan saya; 2) seringkali seperti keadaan saya; 3) hampir seperti keadaan saya; 4) sedikit seperti keadaan saya; dan 5) tidak seperti keadaan saya. Hasil uji reliabilitas terhadap alat ukur ini menunjukkan bahwa seluruh butir yang diuji adalah valid dengan nilai Cronbach's alpha sebesar $\alpha=0,950$. Contoh butir pernyataan dari alat ukur ini adalah "Saya merasa hangat dan nyaman ketika bersama suami/istri saya".

Spiritualitas adalah persepsi emosional dan pengalaman keseharian yang berhubungan dengan transendensi dalam kehidupan berkeluarga pada pasangan suami istri. Data ini diperoleh melalui alat ukur Daily Spiritual Experience Scale yang dikembangkan oleh Underwood dan Teresi (2002). Alat ukur ini mampu mengungkap dua indikator spiritualitas yaitu persepsi subjek tentang adanya sesuatu yang transenden dan keterlibatan subjek dalam berbagai peristiwa transenden. Alat ukur ini menggunakan skala Likert yang terdiri dari lima alternatif jawaban. Instrumen terdiri atas 16 butir pernyataan, namun ada satu butir yang dinyatakan gugur sehingga butir yang digunakan dalam penelitian berjumlah 15 butir pernyataan. Hasil pengujian terhadap alat ukur spiritualitas menunjukkan bahwa ada satu butir yang dinyatakan gugur yaitu butir nomor 13 disebabkan karena bersifat unfavorable "Saya merasa sebagai orang yang kurang peduli terhadap orang lain". Hasil uji reliabilitas terhadap alat ukur ini menunjukkan bahwa seluruh butir yang diuji adalah valid dengan nilai Cronbach's alpha sebesar $\alpha=0,853$. Contoh butir pernyataan dari alat ukur ini adalah "Ketika saya sedang merasa terhubung dengan Allah, saya sampai melupakan kehidupan dunia saya".

Teknik analisis data yang dilakukan terdiri atas tiga jenis analisis, yaitu analisis deskriptif, analisis regresi sederhana, dan analisis regresi dengan moderasi. Teknik analisis deskriptif (descriptive analysis) dilakukan dengan cara membandingkan antara skor mean hipotesis dan skor mean populasi ( $\mu$ ). Hasil tersebut dikelompokkan menjadi tiga kelompok, yaitu: 1) kelompok tinggi diartikan ketika skor mean empiris subjek lebih tinggi dari mean populasi; 2) kelompok sedang diartikan ketika skor mean subjek memiliki skor yang sama dengan skor skor mean populasi; dan 3) kelompok rendah diartikan ketika skor mean empiris subjek lebih rendah dari skor mean populasi (Ferguson, 1981). Teknik analisis regresi ganda (regression analysis) dilakukan untuk menguji pengaruh variabel cinta termasuk komponennya terhadap variabel keharmonisan keluarga. Teknik analisis regresi dengan moderasi (moderated regression analysis) dilakukan untuk menguji pengaruh variabel cinta terhadap variabel keharmonisan keluarga dengan menjadikan variabel spiritual sebagai moderator. Proses analisis selanjutnya adalah analisis dengan program komputer Statistical Package for Social Sciences Versi 23.

\section{HASIL}

\section{Karakteristik Subjek Penelitian}

Penelitian ini melibatkan 205 istri dan 205 suami. Rata-rata usia subjek adalah 38,6 tahun. Rata-rata usia suami adalah 40,2 tahun sedangkan usia istri adalah 36,9 tahun. Sebagian besar subjek bekerja sebagai akademisi baik sebagai guru maupun dosen $(28,8 \%)$. Subjek telah menikah dalam rentang waktu yang cukup lama, lebih dari 10 tahun $(52,7 \%)$ dan sebagian besar status pernikahannya dikategorikan sebagai pernikahan pertama $(96,6 \%)$. Sebagian besar subjek sudah memiliki anak $(82,9 \%)$ dan hanya $17,1 \%$ yang belum memiliki anak. Dilihat dari jenjang pendidikan, ada sebanyak 55,1\% subjek merupakan lulusan dari perguruan tinggi, baik di tingkat S1, S2, maupun S3. Lebih lanjut, hampir setengah (46,1\%) subjek merupakan lulusan S1 (Tabel 1).

\section{Keharmonisan, Cinta, dan Spiritualitas}

Analisis deskriptif menunjukkan bahwa hampir seluruh (97,8\%) subjek memiliki tingkat keharmonisan yang tinggi. Hal ini mengindikasikan bahwa tujuan pernikahan yang mereka harapkan telah tercapai. Hanya ada 2 dari 100 orang subjek yang belum mencapai tujuan tersebut. Hasil analisis selanjutnya menunjukkan bahwa seluruh subvariabel keharmonisan keluarga subjek berada di atas 96 persen. 
Tabel 1 Persentase sebaran responden berdasarkan karakteristik sosial ekonomi

\begin{tabular}{|c|c|c|c|}
\hline Variabel & Kategori & $\mathrm{N}$ & $\%$ \\
\hline \multirow{2}{*}{$\begin{array}{l}\text { Jenis } \\
\text { kelamin }\end{array}$} & Laki-laki & 205 & 50 \\
\hline & Perempuan & 205 & 50 \\
\hline \multirow[t]{4}{*}{ Usia } & Di bawah 30 tahun & 120 & 29,3 \\
\hline & $31-40$ tahun & 111 & 27,1 \\
\hline & $41-50$ tahun & 120 & 29,3 \\
\hline & Di atas 50 tahun & 59 & 14,4 \\
\hline \multirow[t]{6}{*}{ Pekerjaan } & Guru/dosen & 118 & 28,8 \\
\hline & TNI/POLRI & 5 & 1,2 \\
\hline & $\begin{array}{l}\text { Pedagang/Wiraswa } \\
\text { sta }\end{array}$ & 84 & 20,5 \\
\hline & Petani & 25 & 6,1 \\
\hline & Petugas kesehatan & 8 & 2,0 \\
\hline & Lain-lain & 170 & 41,5 \\
\hline \multirow[t]{2}{*}{$\begin{array}{l}\text { Lama } \\
\text { Pernikahan }\end{array}$} & $\begin{array}{l}\text { Kurang dari } 10 \\
\text { tahun }\end{array}$ & 196 & 47,3 \\
\hline & Lebih dari 10 tahun & 216 & 52,7 \\
\hline \multirow[t]{2}{*}{$\begin{array}{l}\text { Status } \\
\text { Pernikahan }\end{array}$} & $\begin{array}{l}\text { Pernikahan } \\
\text { Pertama }\end{array}$ & 396 & 96,6 \\
\hline & $\begin{array}{l}\text { Pernah menikah } \\
\text { sebelumnya }\end{array}$ & 14 & 3,6 \\
\hline \multirow[t]{3}{*}{$\begin{array}{l}\text { Jumlah anak } \\
\text { yang dimiliki }\end{array}$} & Belum punya anak & 70 & 17,1 \\
\hline & $\begin{array}{l}\text { Punya anak } 1-2 \\
\text { anak }\end{array}$ & 223 & 54,4 \\
\hline & Lebih dari 2 anak & 117 & 28,5 \\
\hline \multirow[t]{6}{*}{$\begin{array}{l}\text { Tingkat } \\
\text { pendidikan }\end{array}$} & SD & 13 & 3,2 \\
\hline & SMP & 32 & 7,8 \\
\hline & SMA & 139 & 33,9 \\
\hline & S1 & 189 & 46,1 \\
\hline & S2 & 33 & 8,0 \\
\hline & S3 & 4 & 1,0 \\
\hline
\end{tabular}

Hal ini menunjukkan bahwa subjek terbiasa melakukan komunikasi secara efektif, mampu menyelesaikan konflik yang terjadi, sabar dalam membina hubungan di antara suami istri, merasa bangga dengan identitas keluarga, dan mampu memanfaatkan waktu secara efektif. Hasil analisis pada variabel cinta menunjukkan hasil yang relatif sama dengan variabel keharmonisan keluarga yang mana subjek penelitian memiliki tingkat perasaan cinta sebesar 97,6 persen.

Hal ini mengindikasikan bahwa perasaan cinta yang dimiliki subjek terhadap pasangannya terkategori tinggi. Lebih lanjut, hasil penelitian memperlihatkan bahwa sub-variabel cinta yang paling tinggi skornya yaitu komitmen (98\%) sedangkan yang paling rendah adalah kegairahan $(91 \%)$. Hal ini menunjukkan bahwa subjek lebih memiliki tingkat komitmen yang tinggi dibandingkan dengan kegairahan di antara pasangan masing-masing.

Pada variabel spiritual, secara umum gambaran spiritual subjek berada pada kategori yang sama dengan kedua variabel sebelumnya yaitu terkategori tinggi. Hasil analisis menunjukkan bahwa sub-variabel spiritualitas tentang persepsi terhadap transendensi $(97,56 \%)$ lebih tinggi dibandingkan dengan keterlibatan dalam transendensi $(92,68 \%)$. Hal ini berarti bahwa subjek lebih tinggi pada aspek kognisi dibandingkan dengan aspek pengamalan (Tabel 2).

\section{Cinta dan Keharmonisan Keluarga}

Pada bagian ini diuraikan tiga hasil pengujian statistik. Pertama, pengujian normalitas data melalui teknik Skewness dan Kurtosis yang bertujuan untuk memenuhi prasyarat analisis statistik parametrik (Tabel 3).

Tabel 2 Deskripsi keharmonisan, cinta dan spiritualitas

\begin{tabular}{lrrrrrr}
\hline \multirow{2}{*}{ Nama variabel } & Tinggi & \multicolumn{3}{c}{ Sedang } & \multicolumn{3}{c}{ Rendah } \\
\cline { 2 - 7 } & $\Sigma$ & $\%$ & $\Sigma$ & $\%$ & $\Sigma$ & $\%$ \\
\hline Keharmonisan keluarga & 401 & 97,80 & 1 & 0,24 & 8 & 1,95 \\
$\quad$ Komunikasi efektif & 394 & 96,10 & 4 & 0,98 & 12 & 2,93 \\
Penyelesaian konflik & 396 & 96,59 & 5 & 1,22 & 9 & 2,20 \\
Kesabaran membina hubungan & 358 & 93,41 & 19 & 4,63 & 18 & 4,39 \\
Kebanggaan dengan identitas & 383 & 96,34 & 12 & 2,93 & 9 & 2,20 \\
Pemanfaatan waktu & 395 & 96,34 & 5 & 1,22 & 10 & 2,44 \\
Cinta & 400 & 97,56 & 1 & 0,24 & 9 & 2,20 \\
$\quad$ Keintiman & 401 & 97,80 & 2 & 0,49 & 7 & 1,71 \\
Gairah & 374 & 91,22 & 10 & 2,44 & 26 & 6,34 \\
Komitmen & 403 & 98,29 & 0 & 0,00 & 7 & 1,71 \\
Spiritualitas & 409 & 99,76 & 0 & 0,00 & 1 & 0,24 \\
Persepsi terhadap transendensi & 400 & 97,56 & 5 & 1,22 & 5 & 1,22 \\
$\quad$ Terlibat dalam transendensi & 380 & 92,68 & 7 & 1,71 & 18 & 4,39 \\
\hline Keterang: $\Sigma=$ jum
\end{tabular}

Keteranga: $\Sigma=$ jumlah frekuensi, \%=persentase 
Tabel 3 Hasil analisis deskriptif dan pengujian normalitas data

\begin{tabular}{lrrrr}
\hline Variabel & Mean & $\begin{array}{c}\text { Standar } \\
\text { Deviasi }\end{array}$ & Skewness & Kurtosis \\
& & & & \\
\hline Harmonis & 30,05 & 4,04 & 0,167 & 0,636 \\
Cinta & 208,55 & 27,01 & $-0,198$ & $-0,455$ \\
Intim & 60,71 & 9,64 & $-0,428$ & $-0,149$ \\
Gairah & 63,45 & 9,05 & $-0,141$ & 0,891 \\
Komitmen & 84,38 & 13,55 & $-0,013$ & $-0,358$ \\
\hline
\end{tabular}

Hasil analisis tersebut menunjukkan adanya angka derajat kemiringan dan keruncingan yang memadai pada seluruh variabel yang diuji. Hal ini berarti bahwa seluruh variable yang diuji berada pada kategori normal sehingga penggunaan analisis statistik parametrik dapat digunakan dalam analisis berikutnya. Kedua, hasil analisis deskriptif berupa penghitungan nilai mean dan standar deviasi yang digunakan untuk mengetahui deskripsi setiap variabel yang diuji. Ketiga, hasil analisis regresi yang bertujuan untuk menguji pengaruh variabel cinta terhadap keharmonisan keluarga.

Hasil analisis regresi menunjukkan, cinta berpengaruh terhadap keharmonisan keluarga $(\beta=0,625 p<0,01)$. Lebih lanjut, di antara tiga komponen cinta (keintiman, kegairahan, dan komitmen) hanya keintiman yang berpengaruh secara signifikan $(\beta=0,538 \quad p<0,01)$, sedang komponen kegairahan pengaruhnya terhadap keharmonisan keluarga tidak signifikan $(\beta=0,056 \quad p>0,05)$, demikian juga dengan komponen komitmen $(\beta=0,094 p>0,05)$. Hal ini disebabkan karena indikator dari variabel keharmonisan keluarga (komunikasi yang efektif, penyelesaian konflik, kesabaran dalam membina hubungan, kebanggaan dengan identitas keluarga, dan pemanfaatan waktu) yang diuji dalam penelitian ini tidak berkaitan secara langsung dengan aspek kegairahan yang lebih menekankan pada pentingnya hubungan fisik antara suami dan istri dalam kehidupan keluarga (Tabel 4).

Tabel 4 Hasil analisis interkorelasi antar variabel

\begin{tabular}{llllll}
\hline Variabel & $\begin{array}{l}\text { Harm } \\
\text { onis }\end{array}$ & Cinta & Intim & $\begin{array}{l}\text { Gaira } \\
\text { h }\end{array}$ & $\begin{array}{l}\text { Komit } \\
\text { men }\end{array}$ \\
\hline Harmonis & - & $\begin{array}{l}0,625 \\
* *\end{array}$ & $\begin{array}{l}0,538 \\
* *\end{array}$ & $\begin{array}{l}0,056 \\
\text { ns }\end{array}$ & $\begin{array}{l}0,094 \\
\text { ns }\end{array}$ \\
$\begin{array}{l}\text { Cinta } \\
\text { Intm }\end{array}$ & - & - & - & - & - \\
$\begin{array}{l}\text { Gairah } \\
\text { Komitmen }\end{array}$ & - & - & - & - & - \\
\hline $\begin{array}{l}\text { Keterangan: } \\
\text { signifikan }\end{array}$ & & $-, 005,{ }^{* *}=, 001$ & tingkat & signifikansi, & \\
\end{tabular}

Tabel 5 Hasil analisis dengan variabel moderator

\begin{tabular}{lcccl}
\hline Model & $\beta$ & $t$ & Sig. & Keterangan \\
\hline Cinta & $1,0823,959$ & 0,000 & $\begin{array}{l}\text { Sangat } \\
\text { signifikan }\end{array}$ \\
Spiritualitas & 0,844 & 3,285 & 0,001 & $\begin{array}{l}\text { Sangat } \\
\text { signifikan }\end{array}$ \\
$\begin{array}{l}\text { Interaksi cinta } \\
\text { dan spiritualitas }\end{array}$ & 0,940 & 2,135 & 0,033 & Signifikan \\
\hline
\end{tabular}

Demikian juga dengan aspek komitmen yang lebih menekankan pada pentingnya kesetiaan dan tanggung jawab diantara pasangan suami istri. Selanjutnya, di antara 12 pertanyaan mengenai keintiman ternyata hanya ada 4 pertanyaan yang berpengaruh secara signifikan terhadap keharmonisan keluarga. Keempat pertanyaan tersebut adalah pertanyaan yang berhubungan dengan aspek kebersamaan $(\beta=0,181 \quad p<0,05)$; dukungan emosional $(\beta=0,145 p<0,05)$; pemanfaatan waktu bersama $(\beta=0,145 \quad p<0,05)$; dan saling memahami $(\beta=0,119 \quad p<0,05)$. Hasil analisis di atas menunjukkan bahwa keintiman dalam kehidupan keluarga merupakan aspek yang sangat penting dalam membangun keharmonisan keluarga, dan untuk menciptakan keintiman tersebut dapat dilakukan dengan menciptakan suasana kebersamaan di antara pasangan suami istri.

\section{Peran Spiritualitas sebagai Moderator}

Hasil analisis moderated regresion analysis menunjukkan cinta berpengaruh terhadap keharmonisan keluarga $(\beta=0,625 \quad p<0,01)$, dengan koefisien determinan $R^{2}=0,391$. Hal ini bermakna bahwa keharmonisan keluarga dipengaruhi oleh cinta sebesar 39,1 persen. Selanjutnya, ketika variabel spiritual disertakan dalam analisis sebagai variabel moderator, hasil menunjukkan ada peningkatan skor $(\beta=0,688 p<0,01)$ dengan koefisien determinan sebesar 47,8. Hal ini mengindikasikan bahwa spiritualitas mampu berperan sebagai variabel moderator karena adanya peningkatan sumbangan determinan sebesar 0,87 persen. Hasil ini diperkuat dengan hasil pengujian signifikansi yang menunjukkan interaksi antara cinta dan spiritual $(\beta=0,940 \quad p<0,05)$. Hasil analisis ini memperlihatkan bahwa spiritualitas mampu menjadi penguat pada hubungan antara cinta dan keharmonisan keluarga pada pasangan suami istri (Tabel 5).

\section{PEMBAHASAN}

Hasil penelitian menunjukkan ada tiga temuan penting yang memberi penjelasan mengenai 
hubungan antara cinta, spiritualitas, dan keharmonisan keluarga. Pertama, secara umum cinta berpengaruh secara langsung terhadap keharmonisan keluarga. Artinya, semakin tinggi perasaan cinta pada setiap pasangan suami istri, maka semakin tinggi pula tingkat keharmonisan keluarga. Kedua, di antara tiga indikator cinta, hanya keintiman yang berpengaruh secara signifikan terhadap keharmonisan keluarga, sedangkan indikator kegairahan dan komitmen berpengaruh secara tidak signifikan. Ketiga, kekuatan hubungan antara cinta dan keharmonisan keluarga dapat diperkuat dengan adanya spiritualitas pada pasangan suami istri. Hasil penelitian ini sejalan dengan beberapa penelitian sebelumnya yang mengkaji hubungan antara cinta dan keluarga (Acker \& Davis, 1992; Roberts, 1992) dan spiritualitas dalam hubungannya dengan keluarga (David \& Stafford, 2015; Kaufman et al., 2021).

Cinta dan spiritual adalah dua faktor yang sangat penting dalam mewujudkan keharmonisan keluarga. Hasil ini sejalan dengan beberapa penelitian yang telah dilakukan (Haack \& Falcke, 2014; Kim, KimGodwin, \& Koenig, 2016; Sumption \& Vargas, 2018; Tanyi, 2006). Cinta menjadi faktor yang dijadikan bahan pertimbangan bagi pasangan untuk bersatu dalam membentuk keluarga, sedangkan spiritual merupakan satu kekuatan dari tiap-tiap pasangan untuk lebih memaknai proses kehidupan dalam menjalin hubungan keluarga. Secara umum, cinta memang berpengaruh terhadap keharmonisan keluarga namun dari ketiga faktor cinta yang diuji, hanya faktor keintiman saja yang berpengaruh signifikan. Hasil ini sejalan dengan penelitian yang dilakukan oleh Williams dan Guendouzi (2005) yang menemukan bahwa keintiman adalah faktor yang sangat penting dalam membangun keharmonisan keluarga. Selanjutnya, spiritualitas yang dicirikan dengan adanya kepercayaan terhadap sesuatu yang transenden dan pengalaman spiritual seharihari berperan sebagai variabel moderator pada hubungan kedua variabel yang diuji. Hal ini berarti bahwa cinta merupakan faktor yang sangat penting dalam mewujudkan keharmonisan keluarga dan spiritual adalah faktor yang mampu memperkuat hubungan antara keduanya. Dengan kata lain, untuk mewujudkan keluarga yang harmonis, suami dan istri harus menciptakan sekaligus mempertahankan perasaan cinta, dan hal itu akan semakin kuat pengaruhnya ketika keduanya memiliki pengalaman spiritual yang tinggi.
Keharmonisan keluarga dapat dijelaskan sebagai akibat dari adanya interaksi antara anggota keluarga yang ada di dalamnya. Sementara itu, hubungan antara anggota keluarga, khususnya hubungan antara suami dan istri tidak dapat dipisahkan dari adanya perasaan cinta yang tumbuh sebelum atau selama proses membina hubungan keluarga. Hasil ini sejalan dengan beberapa penelitian yang menunjukkan bahwa cinta berpengaruh terhadap keharmonisan keluarga (Dragojlovic, 2017; Neto, 2012). Salah satu upaya yang dapat dilakukan untuk mengembangkan perasaan cinta antara suami dan istri adalah membangun komunikasi yang harmonis antara keduanya. Hal ini dapat dipahami bahwa perselisihan yang terjadi menunjukkan adanya perbedaan pendapat yang memicu konflik dalam rumah tangga. Perselisihan tersebut diakibatkan bukan karena perbedaan antara suami istri, melainkan karena suami istri tidak mampu hidup di tengah-tengah perbedaan yang ada di antara mereka dan perceraian dapat dipahami sebagai kegagalan suami istri dalam menyelesaikan konflik yang terjadi. Komunikasi yang didasari oleh perasaan cinta di antara pasangan suami istri akan efektif menjadi solusi ketika terjadi konflik di antara mereka. Penelitian yang dilakukan oleh Chuang (2005) membuktikan bahwa komunikasi menjadi faktor yang sangat penting dalam menyelesaikan konflik yang terjadi antara suami istri.

Selanjutnya, penelitian yang dilakukan oleh Haack and Falcke (2014) menemukan bahwa cinta memengaruhi kepuasan pernikahan pada pasangan keluarga pengguna internet. Lebih lanjut, internet mampu menjadi mediator pada hubungan antara cinta dengan kepuasan pernikahan, tapi hubungan secara langsung (face to face) lebih efektif dalam memperkuat hubungan tersebut. Penelitian lainnya dilakukan oleh Ahmetoglu, Swami, dan Chamorro (2010) yang menemukan bahwa keintiman dan komitmen pada Teori Triangular of Love telah berkorelasi positif dengan lamanya membangun suatu hubungan. Namun, ditemukan adanya hubungan yang negatif pada indikator kegairahan. Selanjutnya, mereka memberikan rekomendasi bahwa hasil penelitian ini dapat dijadikan bahan pertimbangan dalam memberikan konseling dan pengembangan keharmonisan pada keluarga. Penelitian Kershaw et al. (2013) menemukan bahwa perasaan cinta suami dapat membantu memulihkan kondisi mental dan kualitas fisik istri selama kehamilan. Selain itu, perasaan cinta, faktor kelekatan, hubungan yang serasi, juga rendahnya tingkat kekerasan 
yang dilakukan suami dapat menyebabkan tingginya tingkat kesehatan mental dan fisik seorang istri.

Perasaan cinta dapat dikembangkan dalam kehidupan keluarga dengan cara memahami bahasa cinta dari pasangannya masing-masing. Chapman (1992) menjelaskan adanya lima bahasa cinta yang harus diperhatikan oleh pasangan suami istri yaitu memberi perhatian, memberikan hadiah, sentuhan fisik, memberikan pujian, dan memberikan pelayanan. Selanjutnya, dikembangkan instrumen pengukurannya dan ditemukan hasil yang memuaskan (Engbert \& Polk, 2006). Penjelasan lebih lanjut dijelaskan bahwa untuk menumbuhkan rasa cinta, maka seorang suami atau istri harus memahami terlebih dahulu jenis bahasa cinta dari pasangannya dan pasangan tersebut harus berusaha untuk bicara dengan bahasa cinta yang dimiliki oleh pasangannya. Cara seperti ini telah dilakukan dalam penelitian Polk dan Engbert (2013) yang menunjukkan bahwa pemahaman terhadap bahasa cinta pasangan mampu meningkatkan rasa cinta di antara keduanya.

Analisis lebih lanjut menunjukkan bahwa untuk membina hubungan antara suami istri maka spiritualitas diperlukan sebagai sarana untuk pedoman dalam menyelesaikan masalahmasalah yang terjadi dalam pernikahan. Penelitian yang dilakukan oleh David dan Stafford (2015) menemukan bahwa komunikasi yang dilandasi dengan spiritualitas mampu meningkatkan kualitas dalam perkawinan. Demikian juga dengan penelitian Fard (2019) yang menemukan bahwa faktor religiusitas berpengaruh terhadap tingkat kepuasan dalam pernikahan. Pentingnya spiritualitas dalam keluarga tidak hanya berpengaruh terhadap keharmonisan tapi juga terhadap pola asuh orang tua dalam mendidik anaknya. Penelitian yang dilakukan oleh Kaufman et al. (2021) mengungkapkan orang tua yang mengasuh anaknya secara positif adalah mereka yang mempunyai tingkat spiritual tinggi. Uraian di atas menunjukkan bahwa spiritualitas dan keberagamaan harus dipertimbangkan dalam upaya menyelesaikan masalah-masalah yang terjadi dalam keluarga (Pandya, 2021).

Keluarga sebagai sebuah sistem dimaknai sebagai hubungan antara satu anggota dengan yang anggota lainnya. Oleh karena itu, perlu ada upaya untuk mengatasi permasalahan serta mempertahankan keharmonisan dalam keluarga. Goode (2009) mengemukakan ada beberapa metode yang dapat dilakukan, yaitu:
1) menekan keinginan individual baik suami maupun istri yang tidak sejalan dengan keinginan pasangan hidupnya; 2) tidak terlalu menganggap penting perselisihan yang terjadi antara suami istri; dan 3) mengajarkan pada anak untuk mempunyai harapan yang sama terhadap sebuah pernikahan sehingga suatu saat nanti ketika sudah menikah akan berperan sesuai dengan harapan dari pasangannya.

Hasil penelitian ini memberikan penjelasan bahwa untuk membangun keluarga yang harmonis diperlukan cinta dan spiritualitas. Kedua modal penting tersebut dapat dikembangkan oleh pasangan suami istri dalam membangun rumah tangga. Pasangan suami istri yang menikah hanya berdasarkan cinta memang memungkinkan untuk mendapatkan keharmonisan, namun keharmonisan tersebut akan menjadi semakin erat dan abadi ketika kedua pasangan tersebut mampu mengembangkan spiritualitas dalam kehidupannya. Hasil penelitian ini semakin menguatkan bahwa peran kehidupan spiritualitas dalam kehidupan suami istri adalah suatu yang krusial.

\section{SIMPULAN DAN SARAN}

Cinta dan spiritual adalah dua faktor penting yang berpengaruh terhadap keharmonisan keluarga. Penelitian ini memberikan penjelasan lebih mendalam bahwa spiritualitas bukan saja berperan sebagai faktor yang berpengaruh terhadap keharmonisan keluarga secara langsung tetapi juga merupakan faktor yang mampu memengaruhi kekuatan hubungan antara cinta dan spiritualitas. Hasil penelitian ini berimplikasi pada pengembangan keharmonisan keluarga yang dapat dilakukan oleh pasangan suami istri dengan cara saling memahami bahasa cinta dari masing-masing pasangan. Selain itu, pasangan dapat terlibat aktif dalam kegiatan keagamaan yang berdampak pada peningkatan kualitas spiritualnya.

Hasil penelitian ini dapat menjadi bahan pertimbangan bagi para pejabat dan pembuat kebijakan di berbagai lembaga seperti Badan Kependudukan dan Keluarga Berencana Nasional (BKKBN), Kantor Urusan Agama (KUA), dan lembaga lain agar lebih memperhatikan bahwa program yang sekarang sudah dilaksanakan baik yang sifatnya preventif (seperti program sosialisasi tentang persiapan berkeluarga pada remaja) maupun program yang bersifat kuratif (seperti program bimbingan 
dan konseling pada pasangan suami istri yang bermasalah) untuk lebih menekankan pentingnya variabel cinta dan spiritualitas sebagai bahan kajian yang harus dipahami oleh masyarakat.

Keterbatasan yang terdapat pada penelitian ini diantaranya adalah dari aspek desain penelitian yang digunakan. Penelitian ini dilakukan dengan pendekatan kuantitatif yang datanya mendasarkan pada angka yang diperoleh melalui skala pengukuran psikologis. Skala yang digunakan dalam penelitian ini telah memenuhi persyaratan reliabilitas sehingga layak untuk digunakan dalam penelitian. Namun, pada satu sisi ada banyak hal yang tidak dapat terungkap melalui pendekatan kuantitatif, misalnya cara dan upaya yang dilakukan suami istri untuk mempertahankan rasa cinta dan menjalani serta mengembangkan kehidupan spiritualnya. Data tersebut tidak mampu terungkap hanya dengan pendekatan kuantitatif. Berdasarkan hal tersebut, saran untuk penelitian selanjutnya dapat mempertimbangkan pendekatan kualitatif atau bahkan pendekatan campuran (mixmethod) kuantitatif-kualitatif dalam upaya untuk memperoleh penjelasan yang lebih mendalam tentang keharmonisan keluarga dan faktor yang memengaruhinya pada kehidupan pasangan suami istri.

\section{UCAPAN TERIMA KASIH}

Penelitian ini didanai oleh oleh Direktur Direktorat Jendral Pendidikan Tinggi Agama Islam (Dirjend Diktis), Kementrian Agama (Kemenag) Republik Indonesia melalui hibah dana penelitian tahun anggaran 2019 yang diberikan oleh Lembaga Penelitian dan Pengabdian Pada Masyarakat (LP2M) Universitas Islam Negeri (UIN) Maulana Malik Ibrahim Malang.

\section{DAFTAR PUSTAKA}

Acker, M., \& Davis, M. H. (1992). Intimacy, passion and commitment in adult romantic relationships: A test of the triangular theory of love. Journal of Social and Personal Relationships, 9(1), 21-50. doi:10.1177/0265407592091002.

Ahmetoglu, G., Swami, V., \& Chamorro, P.T. (2010). The relationship between dimensions of love, personality, and relationship length. Archives of Sexual Behavior, 39(5), 1181-1190. doi:10.1007/s10508-009-9515-5.
Bainah, N. (2013). Faktor-faktor penyebab perceraian di Kelurahan Long Ikis Kabupaten Paser. E-Journal Sosiatri Sosiologi, 1(1), 74-83.

Banker, B. S., \& Gaertner, S. L. (1998). Achieving stepfamily harmony: An intergroup-relations approach. Journal of Family Psychology, 12(3), 310-325. doi:10.1037/0893-3200.12.3.310.

Badan Pusat Statistik (2018). Jumlah Nikah, Talak, dan Cerai di Provinsi Jawa Timur Tahun 2016-2018. Retrieved from https://jatim.bps.go.id/statictable/2019/10/1 1/1848/jumlah-nikah-talak-dan-cerai-diprovinsi-jawa-timur-2016-2018-.html.

Badan Pusat Statistik (2019). Nikah dan Cerai Menurut Kabupaten/Kota di Provinsi Jawa Timur Tahun 2019. Retrieved from https://www.bps.go.id/indikator/indikator/vi ew_data_pub/3500/api pub/VHpUK3MrOVd6dTJjcHdoQ1Z6TGIm UT09/da_04/2.

Chapman, G. (1992). The Five Love Languages:How to Express Heartfelt Commitment to Your Mate. Chicago, IL:Northfield Publishing.

Chrisman, J. J., Chua, J. H., Pearson, A. W., \& Barnett, T. (2012). Family involvement, family influence, and family-centered noneconomic goals in small firms. Entrepreneurship Theory and Practice, 36(2), 267-293. doi:10.1111/j.15406520.2010.00407.x.

Chuang, Y. C. (2005). Effects of interaction pattern on family harmony and well-being: Test of interpersonal theory, relationalmodels theory, and Confucian ethics. Asian Journal of Social Psychology, 8(3), 272-291. 839X.2005.00174.x.

Darokah, M., \& Safaria, T. (2012). Perbedaan tingkat religiusitas, kecerdasan emosi, dan keluarga harmonis pada kelompok pengguna Napza dengan kelompok nonpengguna. Humanitas (Jurnal Psikologi Indonesia), 2(2), 89-101. doi:10.26555/humanitas.v2i2.318.

David, P., \& Stafford, L. (2015). A relational approach to religion and spirituality in marriage: The role of couples' religious communication in marital satisfaction. Journal of Family Issues, 36(2), 232-249. doi:10.1177/0192513X13485922.

Dragojlovic, A. (2017). Age dissimilar couples and romantic relationships: Ageless love? The Asia Pacific Journal of Anthropology, 
18(2),

$189-191$. doi:10.1080/14442213.2016.1233848.

Engbert, N. \& Polk, D., (2006), Speaking the language of relational maintenance: A validity test of Chapman's (1992) five love languages. Communication Research Reports, 23(1), 19-26. doi:10.1080/17464090500535822.

Fard, M. K. (2019). Religiosity and marital satisfaction. Revista de Asistenţă Socială, $18 /(3)$, doi:10.1016/j.sbspro.2013.06.266.

Ferguson, G.A. (1981). Statistical Analysis in Psychology and Education. Tokyo: McGraw-Hill Kogakusha, Ltd.

Fitriyani, A., Suryadi, K., \& Syam, S. (2015). Peran keluarga dalam mengembangkan nilai Budaya Sunda. Sosietas, Jurnal Pendidikan Sosiologi, 5(2), 5-13. doi:10.17509/sosietas.v5i2.1521.

Goode, W. J. (2009) Sosiologi keluarga. Bandung, ID: Bumi Aksara.

Gana, K., Saada, Y., \& Untas, A. (2013). Effects of love styles on marital satisfaction in heterosexual couples: A dyadic approach. Marriage \& Family Review, 49(8), $\quad$ 754-772 doi:10.1080/01494929.2013.834025.

Haack, K. R., \& Falcke, D. (2014). Love and marital quality in romantic relationships mediated and non-mediated by internet. Paidéia (Ribeirão Preto), 24(57), 105-113. doi:10.1590/1982-43272457201413.

Hamidah, Z. (2019). Peran Badan Penasihat, Pembinaan dan Pelestarian Perkawinan (BP4) dalam mencegah perceraian: Studi kasus di KUA Kecamatan Klojen Kota Malang. Hikmatina: Jurnal IImiah Hukum Keluarga Islam, 1(1), 12-23. Retrieved from

http://riset.unisma.ac.id/index.php/jh/article /view/1885.

Hardy, S. A., Zhang, Z., Skalski, J. E., Melling, B. S., \& Brinton, C. T. (2014). Daily religious involvement, spirituality, and moral emotions. Psychology of Religion and Spirituality, 6(4), 338-348. doi:10.1037/a0037293.

Herawati, T., Krisnatuti, D., Pujihasvuty, R., \& Latifah, E. W. (2020). Faktor-faktor yang memengaruhi pelaksanaan fungsi keluarga di Indonesia. Jurnal IImu Keluarga \& Konsumen, 13(3), 213-227. doi:10.24156/jikk.2020.13.3.213.
Johnson, B. E., \& Ray W. (2016). Family systems theory: The wiley blackwell encyclopedia of family studies. New York, NY: Wiley-Blackwell Publishing.

Kaufman, C. C., Howell, K. H., Mandell, J. E., Hasselle, A. H., \& Thurston, I. B. (2021). Spirituality and parenting among women experiencing intimate partner violence. Journal of Family Violence, 36(2), 183193. doi:10.1007/s10896-020-00158-0.

Kavikondala, S., Stewart, S. M., Ni, M. Y., Chan, B. H. Y., Lee, P. H., Li, K.-K., McDowell, I., Johnston, J. M., Chan, S. S., Lam, T. H., Lam, W. W. T., Fielding, R., \& Leung, G. M. (2016). Structure and validity of Family Harmony Scale: An instrument for measuring harmony. Psychological Assessment, 28(3), 307-318. doi:10.1037/pas0000131.

Kershaw, T., Murphy, A., Divney, A., Magriples, U., Niccolai, L., \& Gordon, D. (2013). What's love got to do with it: Relationship functioning and mental and physical quality of life among pregnant adolescent couples. American Journal of Community Psychology, 52(3), 288-301. doi:10.1007/s10464-013-9594-2.

Kim, S.-S., Kim-Godwin, Y. S., \& Koenig, H. G. (2016). Family spirituality and family health among Korean-American elderly couples. Journal of Religion and Health, 55(2), 729746. doi:10.1007/s10943-015-0107-5.

Lam, W. W. T., Fielding, R., McDowell, I., Johnston, J., Chan, S., Leung, G. M., \& Lam, T. H. (2012). Perspectives on family health, happiness and harmony $(3 \mathrm{H})$ among Hong Kong Chinese people: A qualitative study. Health Education Research, 27(5), 767-779. doi:10.1093/her/cys087.

Larasati, A. (2012). Kepuasan perkawinan pada istri ditinjau dari keterlibatan suami dalam menghadapi tuntutan ekonomi dan pembagian peran dalam rumah tangga. Jurnal Psikologi Pendidikan dan Perkembangan, 1(3), 1-6. Retrieved from http://journal.unair.ac.id/filerPDF/alpenia_ri ngkasancorel.pdf.

Lorenzo, B. E. I., Unger, J. B., Baezconde, G. L., Ritt-. O. A., \& Soto, D. (2012). Acculturation, enculturation, and symptoms of depression in hispanic youth: The roles of gender, hispanic cultural values, and family functioning. Journal of Youth and Adolescence, 41(10), 13501365. doi:10.1007/s10964-012-9774-7. 
Maimun, M., Toha, M., \& Arifin, M. (2019). Fenomena tingginya angka cerai-gugat dan faktor penyebabnya: Analisis reflektif atas kasus-kasus perceraian di Madura. Islamuna: Jurnal Studi Islam, 5(2), 157167. doi:10.19105/islamuna.v5i2.2105.

Nasir, B. (2012). Faktor-faktor yang mempengaruhi perceraian di Kecamatan Sungai Kunjang Kota Samarinda. Psikostudia: Jurnal Psikologi, 1(1), 31-48. doi:10.30872/psikostudia.v1i1.2172.

Neto, F. (2012). Compassionate love for a romantic partner, love styles and subjective well-being. Interpersona: $A n$ International Journal on Personal Relationships, 6(1), 23-39. doi:10.5964/ijpr.v6i1.88

Pandya, S. P. (2021). Online spiritual counseling mitigates immigration stress and promotes better marital adjustment of south asian young dual-earner couples who emigrate to western countries. Contemporary Family Therapy, 43(1), 3553. doi:10.1007/s10591-020-09547-5.

Perry, A., Harris, K., \& Minnes, P. (2005). Family environments and family harmony: An exploration across severity, age, and type of DD. Journal on Developmental Disabilities, 11(1), 17-30. Retrieved from https://oadd.org/wp-

content/uploads/2016/12/perryEtAl.pdf.

Polk, D. \& Engbert, N., (2013). Speaking the language of love: On whether chapman's (1992) claims stand up to empirical testing. The Open Communication Journal, 7(1), $1-11$. doi:10.2174/1874916X20130423001.

Roberts, T. W. (1992). Sexual attraction and romantic love: Forgotten variables in marital therapy. Journal of Marital and Family Therapy, 18(4) 357-364. doi:10.1111/j.1752-0606.1992.tb00949.x.

Roksa, J., \& Kinsley, P. (2018). The role of family support in facilitating academic success of low-income students. Research in Higher Education, 60(4), 415-436. doi:10.1007/s11162-018-9517-z.
Siroj, E. Y., Sunarti, E., \& Krisnatuti, D. (2019). Keberfungsian agama di keluarga, ancaman, interaksi teman sebaya, dan religiusitas remaja. Jurnal IImu Keluarga \& Konsumen, 12(1), 13-25. doi:10.24156/jikk.2019.12.1.13.

Slaughter, W. S. (2009). An exploratory study of the determinants of family harmony in family businesses [Tesis]. North-West University. http://dspace.nwu.ac.za/ handle/10394/4157.

Sternberg, R. J. (1997). Construct validation of a triangular love scale. European Journal of Social Psychology, 27(3), 313-335. doi:10.1002/(SICI)10990992(199705)27:3<313::AIDEJSP824>3.0.CO;2-4.

Sumption, M., \& Vargas, S.C. (2018). Love is not all you need: Income requirement for visa sponsorship of foreign family members. Journal of Economics, Race, and Policy, 2(2), 62-76. doi:10.1007/s41996-018-0022-8.

Tanyi, R. A. (2006). Spirituality and family nursing: Spiritual assessment and interventions for families. Journal of Advanced Nursing, 53(3), 287-294. doi:10.1111/j.1365-2648.2006.03731.x.

Underwood, L. G., \& Teresi, J. A. (2002). The daily spiritual experience scale: Development, theoretical description, reliability, exploratory factor analysis, and preliminary construct validity using healthrelated data. Annals of Behavioral Medicine, 24(1), 22-33. doi:10.1207/s15324796abm2401_04.

Wijayanti, U. T. (2021). Analisis faktor penyebab perceraian pada masa pandemi Covid-19 di Kabupaten Banyumas. Jurnal IImu Keluarga \& Konsumen, 14(1), 14-26. doi:10.24156/jikk.2021.14.1.14.

Williams, A., \& Guendouzi, J. (2005). Constructing family relationships: Intimacy, harmony and social value in accounts of sheltered retirement community residents. The Journal of Aging Studies, 19(4), 453470. doi:10.1016/j.jaging.2004.10.002. 